\title{
清末における唯識法相典籍の刊行について
}

陳継 東

清朝期の中国仏教の衰退は，各宗派にとって最も重要とされるべき典籍さえも 多く失われていた当時の文献流通の状況と表裏を成す。唯識法相宗について言え ば，最も基本的な著作と言らべき『因明論疏』，『成唯識論述記』等は，元末より 既に伝を失い，明・清『大蔵経』にはともに欠落していた。欧陽漸（1870-1943） は『瑜伽師地論叙・緒言』で, 清に至っては, 明の『相宗八要』と『唯識心要』 を通じてしか唯識法相学を理解することができないよらになっていた，と指摘し ている。このような状況を背景として, 清末仏教の振興に努力した楊文会（18371911）は，1866年に南京に金陵刻経処を設立し，仏典の収集・刊行に努めた。ま た，日本の友人南条文雄（1849-1927）の協力を得て, 日本・朝鮮などから中国で は五代以後散逸していた重要な経論注疏を約三百種手に入れ，つぎつぎと復刻し て広く流通させた。その中には少なからぬ唯識経典も含まれている。近代の中国 仏教において，もっともめざましい復興を遂げたと言われる唯識学について，こ の楊文会の典籍復刻の活動は決定的に重要である。

（）『清国楊文会請求南条文雄氏送致書目』の中の唯識法相典籍

最近筆者は，成簣堂文庫（扣茶の水図書館）所蔵『清国楊文会請求南条文雄氏送 致書目』一巻一冊 (『新修成筫堂善本書目』(財) 石川文化事業財団・お茶の水図書館1992 年に著録あり。以下『書目』と略記。を)を披閲するを得た。『書目』は，南条文雄から 送られた経典が具体的にどのようなものであったのか, そのうら唯識関係の典籍 は何種類あったか, 又それらの典籍はいつ頃送致されたのか, といった, 従来の 研究では明らかにされていなかった問題について具体的な情報を与えてくれる。

『書目』は，南条文雄らと楊文会との間のやりとりの過程で随時書き継がれた ものと考元られ，まとまって整理されたものではない。今，簡単な分析によれ ば，楊文会からは前後三次の請求書目があり，請求した本は合計202部に上る。そ のらち唯識関係のものと認められる典籍は26部ほどである。それに対して, 明治 24年から26年11月まで南条文雄らから寄送された本は235部が数えられ，そのな かには, 窺基『成唯識論述記』・『成唯識論枢要』・『因明入正理論疏』, 慧沼『成唯 
識論了義灯』, 智周『成唯識論演秘』, 遁倫『瑜伽論記』等約 30 部の法相唯識典籍 が含まれている。〔書目』の性質を知る参考までに，その中の題記を転記する。】

「因ミ二明治二十四年五月ヨリ二十五年十二月マテニ，文雄ヨリ東海玄虎（頃日佐藤茂 信卜氏名 $\ni$ 更改ス), 町田久成, 赤松連城ノ三君二謀り或八楊文会氏二代リテ購七得夕 リ，或八直チニ之ョ寄贈セシ書籍/目録 7 左二附記シ，二年間法宝弘通ノ一班 $\ni$ 挙ヶ テ, 古今ノ異ヨ示サントス」。

\section{(二) 刊行された唯識法相の典籍の種類}

清末に刊行された唯識法相典籍の全貌は未だ明確に把握されるに至らないが, 簡単に例を挙げるならば，まず，金陵刻経処刊行の『解深密経』(1871年)，『成唯 識論』(1896年), 『瑜伽師地論』(1897年前後より1917年に至って完成), 高原『相宗八 要解』(1902年) 及び江西刻経処で刊行された『唯識開蒙』(揚州蔵経禅院版, 1911 年）など，これらはいずれも伝本に基づいて重刻されたものである。一方で, 金陵刻経処所刊の 窥基『因明論疏』・『成唯識論述法』(1901年), 法蔵『楞伽心玄 義』, 又, 江西刻経処で刊行されたもので『唯識二十論』（1910年）、唯識二十 論述記』(1910年) などはいずれも南条文雄等から送られたテキストをもとにした ものである。楊文会はその中の『成唯識論述記』, 『因明論疏』四部, 『入楞伽心 玄義』を南条文雄へ送って謝意を表している。楊文会は又逆に，日本の『続蔵』 の刊行に協力するために, 『唯識開蒙』,『唯識俗詮』,『唯識心要』, 『成唯識論集 解』を南条文雄に貸し与兄ている。

\section{(三) 唯識法相典籍刊行の反響}

楊文会の言葉を借りれば，『成唯識論述記』は中国では元朝末期既に伝本が失 われており，「五百年来，人として見るを得しもの無し。といら状況であった。 このため, 『成唯識論述記』, 『因明大疏』および三個疏の逆輸入は中国の仏教学 者たちに大きな反響を呼びおこし，引いては唯識学の近代における復興の契機と もなった。まずは楊文会によって，『成唯識論述記』を利用して新たに校訂を加 えられた『成唯識論』が公刊され，続いて僧松厳によって『因明大疏』も刊行さ れた。楊文会は南条文雄に宛てた書簡の中でこのように述べている。「貴国より 伝来の『因明大疏』, 比丘の松厳なる者これを愛して刊行せり。ここに四部奉上 す。『唯識述記』等, 又続きて刻する者有り。法相一宗, 晦して復た明かなり。」 又, 「唯識述記』現在既に刻し始めおり, 本年中にその功成るべし。支那の学 者, 貴国より郵来の古本を得て, いずれも深く欣慶し, 皆その大徳弘通の益に感 
じ，東に向いて礼謝して已まず。」(『等不等観雑録』巻八)とも述べている。楊文 会の弟子の梅光羲は, 『瑜伽師地論』に注釈書が無いことを遺憾として, 楊文会 にその注釈を撰述することを求めた。これに対して，楊文会は既に日本より『瑜 伽論記』が伝えられており，それを刊行するつもりであると答えている。又，こ れも楊文会の学生であった夏曽佑（1863-1924）は，中国に逆輸入されたばかりの 『成唯識論述記』を眼にして「狂わんばかりの喜びようであった」(梁啓超による) という。その後, 彼は日本から『俱舎論』, 『成唯識論述記』, 『瑜伽師地論』等の 書を手に入れている。夏曾佑は楊文会に対して, 各方面の助力を募って, 日本か ら伝えられたこれらの唯識関係の書籍を刊行することができれば，「世道人心に おいて将に大益あらん。と勧めている。この他，楊文会の友人でもある官僚文 人文廷式（1856-1904）は，変法運動に参加した為に日本に逃亡したが，その際天 台三大部や『成唯識論述記』等の典籍を収集し, 楊文会に可能な限り早くそれら の典籍を刊行するよう求めている。文廷式は又, 南条文雄に面会した際に, 南条 に，唯識宗を骨幹としてあらゆる哲学を包摂するような著作をものするように勧 めてもいる(『文廷式集（下)』中華書局1993所収『東遊日記』)。これまた文人である 宋恕（1862-1910） も兽て日本を訪れ, 日本で仏典を探訪し, 南条文雄にも面会 し，又特に日本の因明学研究に深い関心を抱いていた（『宋恕集』中華書局1993参 照) これらの諸例からは，楊文会等のように直接仏教界に属する人物たちばかり でなく, 日本を訪れたその他一般の文人, 知識人たちも又, 大きな関心を持って, 唯識及びその他の仏教関係の典籍の捜訪に務めていた状況が窥窅るであろら。

南条らの協力を受けつつ, 楊文会の仏典復刻事業は中国近代仏教学を根底から 支えたのだ，とも言える。楊文会らの刻経事業は今後更に具体的に明らかにされ ていかねばならない。欧陽漸によれば，楊文会の仏教思想は，初めは『大乗起信 論』, 後に浄土, 華厳を経て, 遂に唯識法相に㷌着したという。楊文会によって 最も早くから大量に刊行されたのは浄土と華厳の典籍であり, 唯識法相典籍が多 く翻刻されたのは民国初期である。そして民国期には，欧陽漸を中心とする唯識 学は仏教思想の一大主流を形成し, 欧陽漸が主宰した金陵刻経処は唯識法相典籍 をほとんど翻刻した。刻経事業と当時の仏教学思潮との関係をより精密に検討す ることが将来の課題としてある。

$\langle キ-ワ ー ト ゙\rangle$ 楊文会, 南条文雄, 中国近代仏教学, 唯議法相典籍 